\title{
Sacconereis of Procerastea.
}

\author{
By
}

Yô K. Okada,

Naba, Hyogo-ken (Japan).

With 1 Figure in the Text.

A SAcconereis " captured by the tow-net in the Firth of Clyde," according to W. C. McIntosh (1908, p. 223, Fig. 5 f.), differs from any described female bud of Autolytus, or of its allied genera such as Myrianida or Proceræa of Ehlers, especially in respect to the shape and number of ovigerous sacs, which the animal carries on its ventral side. "It appears to be fully a quarter of an inch in length, and is readily discriminated by the absence of the single ventral egg-capsule, the ova being borne in eight conspicuous globular or pear-shaped sacs."

There is no second record of the particular Sacconereis since then, and the parent stock to which the bud belongs remains, of course, unknown. Very fortunately a similar or perhaps the same type of Sacconereis was captured here in the Plymouth district, two miles east of the Eddystone, by the bottom plankton net, October 4th, 1927, and I am greatly indebted to Mr. F. S. Russell of this Laboratory for bringing it to my notice.

As will be seen in the accompanying figure, the specimen resembles very closely the female bud of Procerastea (compare with Allen's Pl. 12, Fig. 5, 1921), instead of Autolytus. The large red eyes with distinct lenses, the anterior pair being very large and ventral in aspect, are nothing more than a common character of the sexual individuals of the Autolytinæ to which the present stolon must also belong, but the appendages connected with the head are rather short and appear thicker than those of Autolytus or Myrianida. The arrangement of these tentacles and tentacular cirri exactly corresponds to that of Procerastea. The head itself seems to be composed of three segments, but separation into prostomium, buccal segment and first setigerous segment is obscure. The three prostomial appendages are all represented as smooth, tapering tentacles. Behind the dorsal eyes there is on each side a pair of rather slender tentacular cirri, and these are followed by a single dorsal tentacular cirrus, which is well in front of the first setigerous segment. The tentacular cirri are directed forwards over the head, and are smooth and tapering 
like the tentacles. There are, thus, roughly speaking, nine appendages on the head. The three prostomial appendages are comparatively thick, the median one being nearly as long as the two laterals. The dorsal tentacular cirrus of the buccal segment is slightly longer than the ventral and is almost as long as the similar appendage of the first setigerous segment.

McIntosh has figured a long tentacular cirrus on each side of the succeeding setigerous segments, but in my specimen the $2 \mathrm{nd}, 3 \mathrm{rd}, 4 \mathrm{th}$, and 5 th segments have no such elongated cirri. The dorsal cirrus in these segments is " a large rounded lobe or swelling of somewhat transparent tissue which occupies the posterior dorso-lateral angle of the segment" (Allen, l.c., p. 135), exactly as in the female bud of Procerastea Halleziana (see again Allen's Pl. 12, Fig. 5, 1921). In the 6th setigerous segment the dorsal cirrus is somewhat elongate and tapering toward the tip, but there is still no sign of metamorphosis in the parapodium. With the 7th setigerous segment the special modifications for swimming commence, and the number of modified segments is exactly 14, as in McIntosh's specimen, as well as in the female stolon of P. Halleziana in Allen's Pl. 12, Fig. 5. Behind the 20th or last modified segment the notopodia and the swimming setæ are absent, as in the part in front of the 7th setigerous segment, but the dorsal cirri still persist, at first as short tapering processes similar to those in the 6th segment. McIntosh has drawn a pair of long tentacular cirri in each of the segments back to the end of the body. The short tapering cirri in my specimen, however, gradually reduce in length as we proceed backwards, and soon become replaced by small knobs of transparent-looking tissue, like those seen in the anterior unmodified segments. In the Sacconereis in question there are 32 setigerous segments in this posterior region, while the tapering cirri are observed only in the first 4 or 5 segments. The last setigerous segment is followed by the pygidium with the anal cirri as usual.

Eight ovigerous sacs, nearly of the same size, $0.7 \mathrm{~mm}$. long and $0.5 \mathrm{~mm}$. wide, are all of a similar pear shape. They are fixed on the ventral surface of the modified mid-segments in such a way that 4 occur on each side, arranged alternately.

Finally, as to the genetic relationship of the stolon in question, we are almost certainly dealing with the sexual individual of Procerastea, and not with such an individual of Autolytus, Proceræa, Myrianida, or Virchowia. Moreover, the parent stock of Procerastea Halleziana does not seem to be rare in this part of south England (Allen, 1921). The Syllid is also described from Boulogne (Malaquin, 1892; Caullery, 1925) and Helgoland (Langhammer, 1928), and in these districts it is found closely associated with colonies of Tubularia. At Plymouth the animal lives upon Syncoryne as well as on Tubularia. 


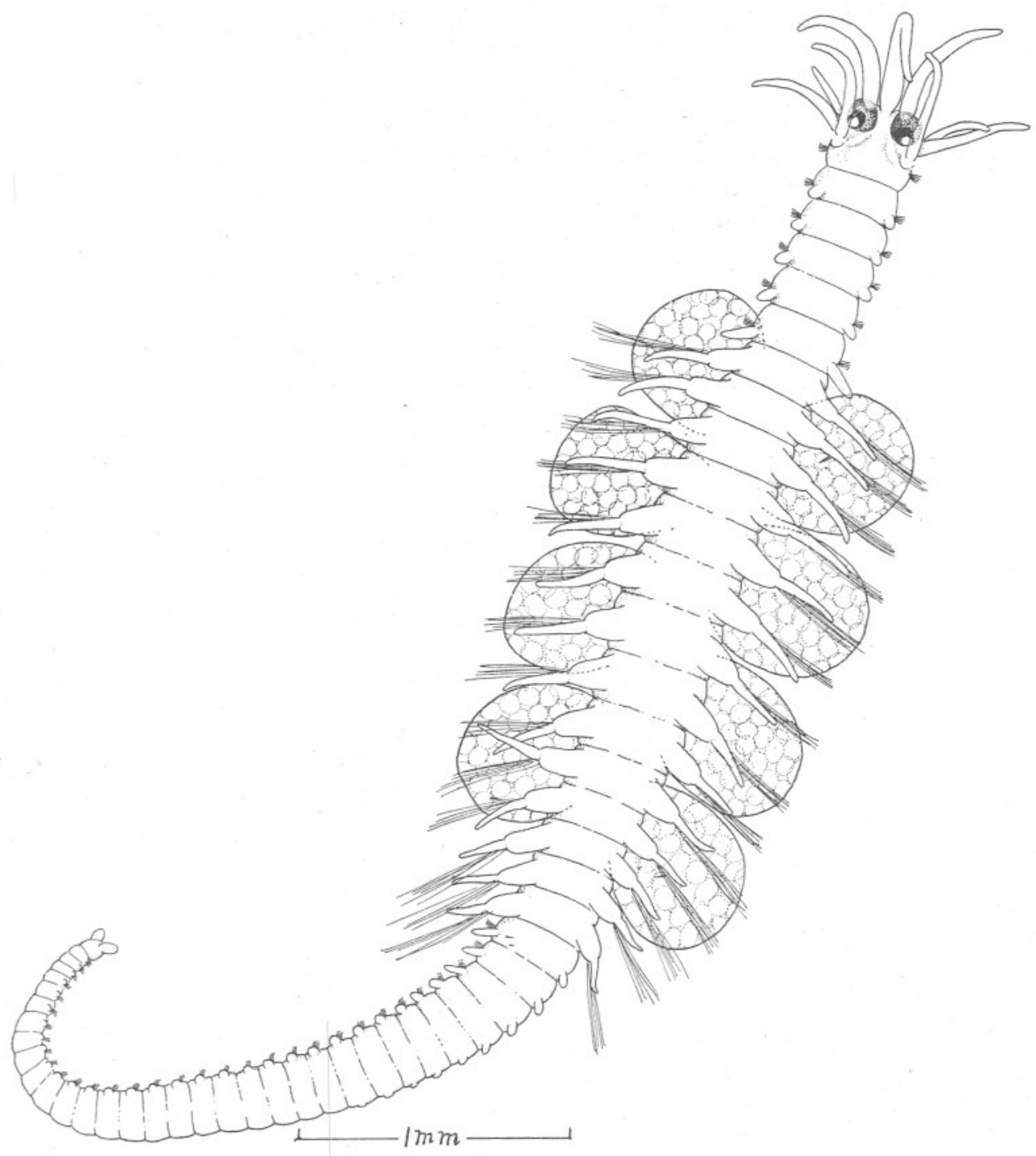

Fro. 1.-Sacconereis, probably of Procerastea Halleziana, captured two miles east of the Eddystone. October 4th, 1927. 


\section{REFERENCES.}

Allen, E. J. 1921. Regeneration and Reproduction of the Syllid Procerastea. Phil. Tr. R. Soc., London, (B) Vol. 211, p. 131.

Caullery, M. 1925. Schizogenèse et Schizogamie de Procerastea halleziana Malaquin, Parasitisme de ce Syllidian sur les Tubularies. Biol. Soc. Zool., Paris, T. 50, p. 204.

Langhammer, H. 1928. Teilungs- und Regenerations-Vorgänge bei Procerastea halleziana und ihre Beziehung zu der Stolonisation von Autolytus prolifer. Wissensch. Meeresuntersuch. Abt. Helgoland, XVII, 1, 1928.

McIntosh, W. C. 1908. A monograph of the British Marine Annelids, Vol II, Polychæta, Pt. 1. The Ray Society, London. 